Andrej Naterer ${ }^{1}$

Faculty of Arts, University of Maribor, Slovenia

Mojca Marič ${ }^{2}$

Faculty of Arts, University of Maribor, Slovenia

Lucija Dežan ${ }^{3}$

Faculty of Arts, University of Maribor, Slovenia

Miran Lavrič ${ }^{4}$

Faculty of Arts, University of Maribor, Slovenia
Оригинални научни рад

UDK 316.64-053.81:314.7

Примљено: 3.11.2019.

Ревидирана верзија: 16.1.2020.

Одобрено за штампу: 17.1.2020.

DOI: https://doi.org/10.46630/gsoc.23.2019.02

\title{
ARE BETTER-OFF YOUTH LESS FEARFUL OF IMMIGRANTS AND REFUGEES? A STUDY OF ATTITUDES AMONG YOUTH IN SOUTHEAST EUROPE
}

\begin{abstract}
A number of studies link higher levels of education and general wellbeing to lower levels of xenophobia and social distance in relation to strangers. We tested this general assumption on a sample of more than 10,000 young people aged from 14 to 29 years from ten countries of Southeast Europe. More specifically, the focus of our research was to evaluate the effect of young people's financial status, parental education and self-rated health onto the level of fear and social distance expressed in relation to immigrants and refugees. Our hypothesis was that better-off young people in all three dimensions (money, education, and health) should be less fearful and more open towards immigrants and refugees in each of the ten countries observed. The analyses showed that none of the six tested hypotheses could be confirmed. With very rare exceptions, better-off young people do not hold more positive perceptions when it comes to immigrants and refugees. In essence, our results suggest that negative perceptions in relation to immigrants and refugees are quite evenly spread across the different segments of young people in terms of their financial situation, cultural background and their health. The only partial exception is Bulgaria, where correlations tend to run contrary to our expectations; better financial situation and better self-rated health are related to more negative perceptions of immigrants and refugees.
\end{abstract}

Keywords: Immigrants, Refugees, Young people, Southeast Europe, Fear, Social Distance

\footnotetext{
${ }^{1}$ andrej.naterer@um.si

2 mojca.maric@guest.arnes.si

${ }^{3}$ lucija.dezan@student.um.si

${ }^{4}$ miran.lavric@um.si
} 


\section{Introduction}

Following the influx of immigrants to Europe in recent years, studies of attitudes towards immigrants and refugees have proliferated and often depict increases in negative attitudes (Davidov, Seddig, Gorodzeisky, Raijman; Markaki, Y., and Longhi, S. 2012; Meuleman, Davidov and Billiet 2009; Rustenbach 2010; Semyonov, Raijman and Gorodzeisky 2006). Many studies show that the Europeans perceive immigrants as a threat to social order, social cohesion, traditions and norms (Ceobanu and Escandell 2010; Davidov et al., 2019; Rustenbach 2010) and as a social, symbolic, economic and criminal danger to both individuals and society (Heath, Davidov, Ford, Green, Ramos and Schmidt 2019; Martínez Guilllem 2018).

Within the social sciences, there are several theoretical explanations of indicators and predictors of public attitudes toward immigrants, yet there is no unified theory explaining these attitudes. On the individual level, most studies focus on socio-demographic characteristics, socioeconomic position, and political attitudes as determinants of attitudes toward immigrants. Commonly, studies suggest that poor socio-economic position, unemployment and low income influence the development of negative perception (Coenders and Scheepers 2003; Gorodzeisky 2011, Hainmueller and Hiscox 2007; Krange 2001; Kunovich 2004; Mierina and Koroleva 2015; O'Rourke and Sinnott 2006; Paas and Halapuu 2012; Roots, Masso and Ainsaar 2016; Vlase and Preoteasa 2017) due to perception of immigrants as competitors for resources that are necessary for survival.

Negative attitudes toward immigrants increase when low levels of socioeconomic status coincide with low levels of education. Individuals with higher levels of education are more favourable towards immigrants (Herreros and Criado 2009; Krange 2001; Rustenbach 2010), since educational systems tend to promote acceptance of different cultural values and beliefs (Espenshade and Calhoun 1993; Hainmueller and Hiscox 2007), thus promoting cultural and social openness. At the same time, immigrants in the labour market mostly work in low-skilled manual jobs and are therefore not perceived as a threat to people with higher levels of education (Hainmueller and Hiscox 2007; Krange 2001; Mayda 2005; O’Rourke and Sinnott 2006). A higher proportion of unskilled immigrants also implies higher wages for skilled workers (Mayda 2005). Unemployed people, unskilled workers, and low-skilled natives are therefore more likely to have negative attitudes towards immigrants because of the fear of losing a job or anger due to unemployment (Gorodzeisky 2011; Krange 2001; O'Rourke and Sinnott 2006). Furthermore, Rustenbach (2010) emphasizes that people appear less tolerant toward immigrants because of the perception that economic competition indeed exists and tied to frequent media portrayals of impoverished immigrants and refugees moving to wealthier countries to improve their standard of living. Some authors emphasize that these perceptions and attitudes depend on the economic state of the country. Some studies suggest that in poor countries, highly-skilled workers appear more 
anti-immigrant than unskilled workers (O'Rourke and Sinnott 2006). Various studies have shown that regardless of their skill level, people will have higher antiimmigrant attitudes when they live in regions where there is a high competition for jobs accompanied by high unemployment rates (Gang, Rivera-Batiz and Yun 2002; Meuleman, Davidov and Billiet 2009; Rustenbach 2010).

The role of education in the development of these attitudes is of particular importance for young people, since their attendance in school is mandatory. Apart from offering education and skill development, these programmes often include some options for international mobility of students, such as Erasmus + . Several researchers list the experience of mobility as an important factor of influencing attitudes toward immigrants on an individual level (O'Rourke and Sinnott 2006). Such experiences educate young people about other social environments, exposing them to other social and cultural influences, and enabling them to form bonds with peers from other countries, thus promoting openness and tolerance.

Within the family context, there are several important factors that influence the attitudes of young people toward immigrants. Firstly, attitudes appear to be influenced by their parents' origin (O'Rourke and Sinnott 2006), and young people with nationally and ethnically diverse backgrounds appear to be more receptive toward immigrants. Hence, those who have already lived abroad and were either born abroad, or with foreign-born parents, are more likely to view diversity as a benefit rather than a cost (O’Rourke and Sinnott 2006). However, Mierina and Koroleva (2015) discovered the opposite: young people born outside the country bear more negative attitudes towards minority groups than those born in the country of residence; in addition, the ethnic minorities do not demonstrate more empathy towards immigrants than the majority of young people. Secondly, attitudes toward immigrants and refugees appear to be influenced by religious background. O'Rourke and Sinnott (2006) discovered that Western Catholics are less anti-immigrant than other western respondents, but Catholicism has no effect on attitudes in the East. Thirdly, attitudes toward immigrants and refugees appear to be influenced by interpersonal trust (Rustenbach 2010) as the results show that national-level interpersonal trust may be too variable to influence an individual's attitudes toward immigrants. In contrast, when interpersonal trust is higher at a regional level, it is likely to influence individuals to be more trusting of immigrants. Therefore, interpersonal trust is recognized as a strong predictor of antiimmigrant attitudes: anti-immigrant attitudes are therefore lower among individuals who have higher levels of interpersonal trust (societal integration) (Rustenbach 2010). Fourthly, attitudes toward immigrants and refugees appear to be influenced by cultural capital and socialization (Krange 2001). According to the power theory, anti-immigrant attitudes tend to grow along with low cultural capital, and Krange (2001) suggests that socialization and class culture should be taken into account when researching attitudes toward immigrants. Finally, attitudes toward immigrants and refugees seem to be influenced by an individual's feeling of neighbourhood safety (see Chandler and Tsai 2001). For instance, individuals who experience fear of crime and fear for their safety, act more protectively and more anti-immigrant. 
Within our analysis, we explore the idea that an increase in levels of individual socio-economic well- being increases of one's openness toward immigrants. Wellbeing shows a strong linkage to economic development (Inglehart 2000) and highincome countries show an increase in both happiness and interpersonal trust which, according to Inglehart, should be understood as a part of the change from survival to self-expression values:

These values bring increasing emphasis on the civil and political liberties that constitute democracy, which provides broader latitude for people to pursue freedom of expression and self-realization. Rising self-expression values transform modernization into a process of human development, generating a society that is increasingly people-centred. This reflects a humanistic transformation of modernity. (Inglehart 2005: 3)

The connection between economic development and tolerance, which is one of the key components of the survival/self-expression dimension, is particularly strong (Inglehart 2005). Many studies support this assumption and show that economic development decreases individual tolerance of inequality (Kelley, Evans, Haller, Jowell and Smith 2009) while increases tolerance toward other social groups, in particular homosexuals (Inglehart 2005; Florida, Mellander and Stolarick 2010; Berggren and Nilsson 2013) and immigrants (Das, DiRienzo and Tiemann 2008). These results should be understood following the assumption that socioeconomic modernization enables the development of objective capabilities for humanist culture and thus induces both cultural transformation on the level of society and behaviour on an individual level.

Socio-economic predictors of attitudes of young people towards immigrants have been relatively little studied in the region of the Southeast Europe. A few studies that exist are mostly limited either to a particular state, or national context (Dimitrova, Buzea, Ljujic and Jordanov 2015) and rarely focus on specific intersection between young people and attitudes towards immigrants and refugees. Our study attempts to bring into focus the fear of immigrants as expressed by young people from Slovenia, Croatia, Bosnia and Herzegovina, Serbia, Romania, Bulgaria, Northern Macedonia, Montenegro, Kosovo, and Albania. Our research is based on a total sample of more than 10,000 young people, aged from 14 to 29 years. We hypothesize that:

1. (H1) in all 10 countries, the economic situation of young individuals correlates negatively with fear of immigrants. This hypothesis is based on research results indicating that individuals with lower economic backgrounds tend to harbour negative attitudes towards immigrants (Coenders and Scheepers 2003; Gorodzeisky 2011, Hainmueller and Hiscox 2010; Krange 2001; Kunovich 2004; Mierina and Koroleva 2015; and O'Rourke and Sinnott 2006);

2. (H2) in all 10 countries, the educational level of a young individual's parents correlates negatively with fear of immigrants. This hypothesis is based on research results indicating that higher parental education tends to exert a positive impact on openness towards immigrants (Miklikowska 2017; Margaryan, Paul, Siedler 2018); 
3. (H3) in all 10 countries, the level of self-rated health of young individuals correlates negatively with fear of young people towards immigrants. This hypothesis is based on research results indicating that high levels of selfrated health and other elements of subjective well-being exert a positive impact on peace, openness, and tolerance (Diener and Tov 2007);

4. (H4) in all 10 countries, the economic situation of a young individual correlates negatively with social distance towards immigrants. This hypothesis is based on research results indicating that an individual's economic background correlates with social distance toward immigrants and other social groups (Pamporov 2009; Goldschmidt and Rydgren 2017);

5. (H5) in all 10 countries, the educational level of a young individual's parents correlates negatively with social distance towards immigrants. This hypothesis is based on the logical assumption that parents with higher education exhibit more tolerant and inclusive behaviour and, in consequence, strive to diminish social distance, an assumption that is also supported by research results (Cavaille and Marshall 2017); and

6. (H6) in all 10 countries, the level of self-rated health of young individuals correlates negatively with social distance towards immigrants. This hypothesis is based on research results indicating that high levels of selfrated health and other elements of subjective well-being exert a positive impact on peace, openness, and tolerance (Diener and Tov 2007), thus diminishing social distance.

\section{Method}

All analyses in this article were made on survey data gathered within the project "Youth in Southeast Europe 2018," which was commissioned by the Friedrich-EbertStiftung (FES) and conducted in early 2018 in ten countries of Southeast Europe: Albania, Bosnia and Herzegovina $(\mathrm{BiH})$, Bulgaria, Croatia, Kosovo, Northern Macedonia, Montenegro, Romania, Serbia, and Slovenia.

\section{Sample}

In each country, the surveys were carried out on representative randomized samples of young people aged 14 through 29 . Samples were sorted along several key socio-demographic characteristics, such as age, gender, place of residence, and type of settlement. The average age of respondents was 21.9 years, ranging from 21.1 in Albania to 22.6 in Romania. The sample consisted of $50.2 \%$ male and $49.8 \%$ female respondents; the number of female respondents ranged from $46.7 \%$ in Kosovo to $51.5 \%$ in Montenegro. The sample size varied from $\mathrm{N}=711$ in Montenegro to $\mathrm{N}=$ 1,500 in Croatia. The average response rate was $64 \%$, varying from $38 \%$ in Kosovo 
to $83 \%$ in Northern Macedonia. In Albania, Bulgaria, Croatia, Kosovo, Romania, and Slovenia, the data were weighted to better fit the target population.

\section{Instrument and data collection}

The same core questionnaire with 127 questions, many of them consisting of several Likert-type items, was administered in each of the ten countries. The questionnaire was constructed by a team of experts in English and then, using a forward-backward procedure, translated into local languages. It was designed particularly broadly in order to shed light on all major issues concerning young people's lives in the region.

\section{Measures and Analytical procedures}

Our focus was to measure the attitudes and beliefs of young people toward immigrants by observing the level of fear and the social distance they express to a variety of fear factors and social groups. When analysing fear, we asked respondents to what extent they were frightened or concerned in relation to the following things: being a victim of physical violence, getting robbed by someone, getting seriously ill, having no job, terrorist attack, war in the region/the world, pollution and climate change, increasing poverty in society, social injustice, corruption, and too many immigrants and refugees. Their answers were measured on a scale from 1 to 3 , with 1 corresponding to"not at all" and with 3 equivalent to "a lot." We calculated the extent of fear towards immigrants and refugees by taking into consideration the mean values of other fear factors. Thus, we computed a measure that we called "relative fear in relation to immigrants" by way of dividing the level of fear of immigrants and refugees by the average level of fear in relation to all other fear factors stated above.

When analysing social distance toward immigrants and other social groups, we asked respondents how they would feel if one of the following families or persons moved into their neighbourhood. We included the following groups: a local family with many children, a homosexual person or a couple, a group of students, a Roma family, a retired couple, drug addicts, ex-prisoners, a family from Western Europe, and refugees. Their answers were measured on a 1-5 Likert scale (1 being "very good" and 5 being "very bad"). The calculation of social distance towards refugees consists of social distance towards refugees divided by the average social distance towards all other groups stated above. Hence, we called the resulting variable "relative social distance towards refugees". 
Results

We begin by focusing on differences between countries in terms of relative fear and relative social distance in relation to immigrants.

Graph 1: Mean values of relative fear and social distance toward immigrants and refugees

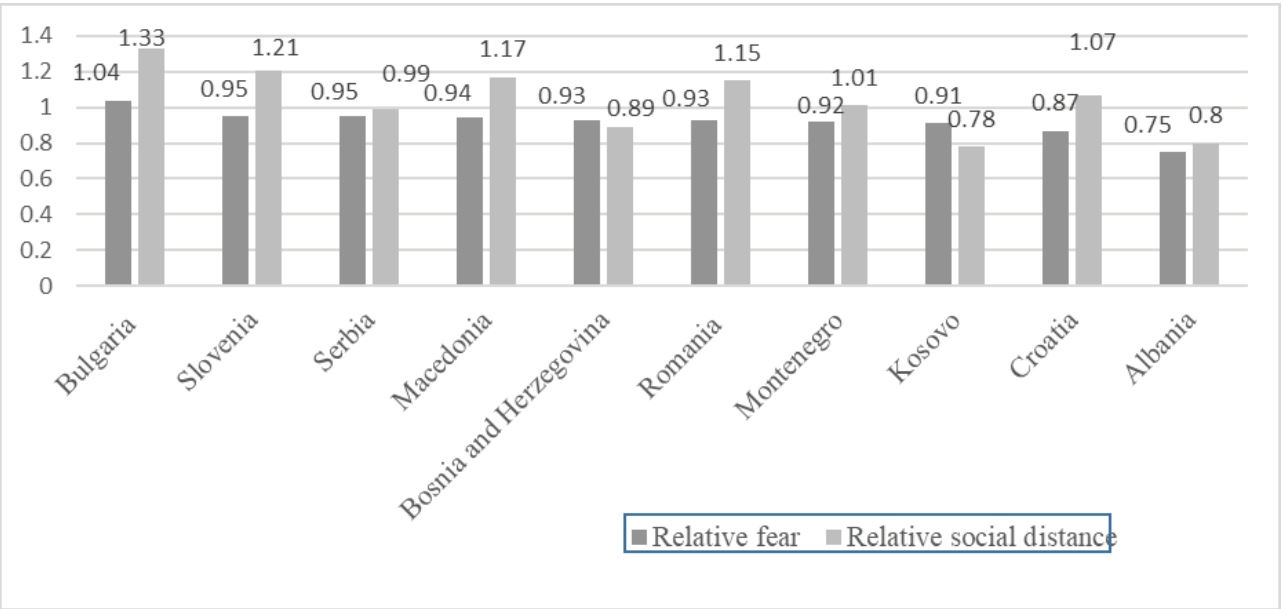

Note: Values indicate the ratio between answers in relation to immigrants and the average of answers in relation to other groups/concerns. For example, the value 1.04 for Bulgaria means that among young people from Bulgaria, fear of immigrants is 4\% stronger in comparison to all other fears measured in the survey. Similarly, a value of 1.33 means that social distance towards immigrants is 33\% higher in Bulgaria than average social distance in relation to other groups.

As shown in the graph above, the young people from Bulgaria express the highest amount of relative fear $(\mathrm{M}=1.04)$ and relative social distance $(\mathrm{M}=1.33)$ towards immigrants among the ten countries. This was the only country where the amount of fear and social distance concerning immigrants exceeded other factors associated with fear and social distance.

Interestingly, there are minimal differences when comparing the rest of the countries studied; Serbia, Slovenia, Northern Macedonia, Bosnia and Herzegovina, Romania, Montenegro, and Kosovo all exhibit similar results. The mean values of relative fear toward immigrants were between 0.95 and 0.91 , indicating that young people in these countries feel slightly less afraid of or distant from immigrants than other social groups or events. The more significant decrease is seen in the case of Croatia $(\mathrm{M}=0.87)$ and Albania $(\mathrm{M}=0.75)$, where young people reported substantially lower values of fear of immigrants in comparison with fear in relation to other social groups or events. Young people from Croatia, however, displayed quite high levels of relative social distance from refugees. Looking at both measures together, Albania and Kosovo appear to be the two countries with the lowest relative fear of and social 
distance from immigrants and refugees.

We continue by focusing on the hypotheses formulated in the introduction. Within our first hypothesis, we assumed that young people from financially more stable households express less relative fear of immigrants.

Table 1: Correlations between self-rated health, household financial situation, parents' education, and relative fear of immigrants

\begin{tabular}{lcccc}
\hline Country & $\begin{array}{l}\text { Household } \\
\text { Financial Situation }\end{array}$ & $\begin{array}{l}\text { Father's } \\
\text { education }\end{array}$ & $\begin{array}{l}\text { Mother's } \\
\text { education }\end{array}$ & Self-rated health \\
\hline & & & & \\
Albania & -0.024 & 0.036 & $0.063^{*}$ & 0.016 \\
Bosnia and Herzegovina & -0.011 & 0.006 & 0.006 & $-0.103^{* *}$ \\
Bulgaria & $0.125^{* *}$ & 0.000 & 0.047 & 0.039 \\
Croatia & -0.023 & -0.021 & 0.001 & $-0.079^{* *}$ \\
Kosovo & -0.017 & 0.026 & 0.053 & -0.017 \\
Northern Macedonia & 0.038 & -0.013 & 0.012 & -0.014 \\
Montenegro & -0.024 & 0.040 & -0.021 & 0.048 \\
Romania & $-0.096^{* *}$ & 0.037 & 0.030 & 0.059 \\
Serbia & $-0.076^{*}$ & -0.002 & -0.012 & 0.018 \\
Slovenia & 0.032 & -0.021 & -0.024 & 0.057 \\
\hline
\end{tabular}

**. Correlation is significant at the 0.01 level (1-tailed).

*. Correlation is significant at the 0.05 level (1-tailed).

The results from table 1 show a weak negative correlation between households' financial situation and fear of immigrants in Romania $(r=-0.096, p<0.01)$ and Serbia $(r=-0.076 . p<0.05)$. Thus, if these two countries were the only ones in our sample, we could confirm our first hypothesis. However, we must reject our $\mathrm{H} 1$, since correlations are not statistically significant in most countries, while in Bulgaria, better-off young people are even slightly more fearful of immigrants and refugees $(\mathrm{r}=0.125, \mathrm{p}<0.01)$.

In our second hypothesis (H2), we assumed that young people with better educated parents express less fear towards immigrants. Among all countries, the correlation was statistically significant only in the case of Albania and only for the mother's education $(r=0.063, \mathrm{p}<0.05)$. Furthermore, this correlation was positive, which directly contradicts our second hypothesis, making it clear that $\mathrm{H} 2$ must be rejected.

Regarding health (H3), we hypothesized that individuals rating their health higher express less fear of and concern toward immigrants. While this can be confirmed for Bosnia and Herzegovina $(r=-0.103, \mathrm{p}<0.01)$ and Croatia $(\mathrm{r}=-0.079$, $\mathrm{p}<0.01$ ), correlations for other countries are not statistically significant. Therefore, we must reject our third hypothesis. 
Table 2: Correlations between household financial situation, parents'education, self-rated health, and relative social distance from refugees.

\begin{tabular}{lcccc}
\hline Country & $\begin{array}{c}\text { Household Financial } \\
\text { Situation }\end{array}$ & $\begin{array}{c}\text { Father's } \\
\text { education }\end{array}$ & $\begin{array}{c}\text { Mother's } \\
\text { education }\end{array}$ & Self-rated health \\
\hline Albania & & & & \\
Bosnia and Herzegovina & 0.015 & -0.025 & -0.043 & 0.014 \\
Bulgaria & 0.013 & 0.062 & 0.023 & -0.037 \\
Croatia & 0.066 & $0.073^{*}$ & $0.145^{* *}$ & $0.143^{* *}$ \\
Kosovo & $0.053^{*}$ & 0.025 & 0.013 & $-0.117^{* *}$ \\
Northern Macedonia & -0.011 & -0.053 & -0.050 & -0.005 \\
Montenegro & $0.143^{* *}$ & -0.064 & -0.024 & 0.040 \\
Romania & -0.003 & 0.018 & 0.004 & 0.032 \\
Serbia & -0.056 & 0.010 & 0.011 & 0.040 \\
Slovenia & 0.056 & -0.038 & -0.056 & $0.066^{*}$ \\
\hline
\end{tabular}

**. Correlation is significant at the 0.01 level (1-tailed).

*. Correlation is significant at the 0.05 level (1-tailed).

Within our fourth hypothesis (H4), we assumed that financially more stable households exhibit lower social distance from refugees. Contrary to what was expected, the results presented in Table 2 show a positive correlation between a household's financial situation and social distance in Northern Macedonia ( $\mathrm{r}=$ $0.143, \mathrm{p}<0.01)$ and Croatia $(\mathrm{r}=0.053, \mathrm{p}<0.05)$, while no statistically significant correlation was found in other countries. Consequently, $\mathrm{H} 4 \mathrm{had}$ to be rejected.

The case with our fifth hypothesis is similar. While we hypothesised that the relative social distance from refugees should be lower among young people with more educated parents, the opposite is the case in Bulgaria where children of more educated mothers $(r=0.073, p<0.05)$ and fathers $(r=0.145, p<0.01)$ exhibit even higher relative social distance. In other countries, correlations are not statistically significant, leaving us with no other choice but to reject H5.

Finally, we hypothesised that the relative social distance from refugees should be lower among young people with better self-rated health. Indeed, this proved to be the case in Croatia $(\mathrm{r}=-0.117, \mathrm{p}<0.01)$. However, the opposite was the case in Bulgaria $(\mathrm{r}=0.143, \mathrm{p}<0.01)$ and Serbia $(\mathrm{r}=0.066, \mathrm{p}<0.05)$, while no statistically significant correlation was found in other countries. Therefore, even our last hypothesis had to be rejected.

\section{Discussion}

In this study, we set out to explore whether better-off young people across the countries of Southeast Europe were less fearful of - or reluctant to live with immigrants or refugees. Despite the fact that we found a body of literature supporting this idea, our findings suggest that the answer to this question is a resolute no. 
Our first finding that provided general overview and comparison of young people's opinion was that Bulgarian youth conveyed the highest amounts of fear and social distance toward immigrants among all 10 countries. These findings are congruent with a paper presented by Ivanova (2018), who reports of existence of a Bulgarian notorious group called Refugee hunters that represents a physical threat to immigrants and enjoys public support. According to Ivanova (2018), approximately $70 \%$ of Bulgarians perceive immigrants as a national threat, a burden to the economy and a cultural threat that will spread Islam in Europe. Many Bulgarians believe that immigrants cannot be integrated, which is largely instigated by hate speech that is spread through the media. Furthermore, young people are often concerned about obtaining a job, which is yet another factor that can cause fear and distrust, since newcomers are perceived as potential competition. On the other hand, it is worth noting that Albania and Kosovo were countries with the lowest relative fear of and social distance from immigrants and refugees. These two countries are among the least economically developed countries in our sample. The fact that the highest levels of relative fear of and social distance from immigrants appear to be present among young people from the much more highly developed Bulgaria and Slovenia, can be taken as a sign that economic welfare might not actually be a defining predictor of more favourable attitudes towards immigrants on an individual level.

Additionally, our findings indicate that better financial situation of the household does not make young people less fearful of immigrants and refugees in eight out of ten countries observed - the two exceptions being Romania and Serbia. It turned out that in Bulgaria, better-off young people are even slightly more fearful of immigrants and refugees. This finding, again, resonates well with the results published by Ivanova (2018), indicating that in comparison to people from other countries, Bulgarians generally appear less supportive of immigrants, regardless of their financial status. We assume that once such attitudes become mainstream, they are also accepted by the young people with higher economic status.

The results also showed the absence of the expected effect of a better financial situation on lower social distance and fear toward refugees. This effect is absent in all ten countries. Furthermore, in Bulgaria, better financial situation is associated with higher levels of relative fear of immigrants and refugees, while in Northern Macedonia, better-off young people exhibit higher levels of relative social distance from refugees. In short, none of the ten countries proves that a better financial situation of young persons' households would be conducive to more favourable attitudes towards immigrants and refugees in both dimensions used in our study.

Moreover, our findings suggest that even higher parental education does not reduce fearfulness of or social distance in relation to immigrants and refugees. Albanians whose mothers achieved higher education, tend to report even higher levels of fear, while in Bulgaria, the children of more educated parents exhibit substantially higher social distance toward refugees.

When it comes to self-rated health, our results show that healthier young people from $\mathrm{BiH}$ and Croatia tend to be less fearful of immigrants and refugees. In Croatia, healthier young people also reported lower levels of social distance toward refugees. 
However, in all other countries, correlations were either statistically insignificant, or running in the opposite direction. The latter was found in Bulgaria and Serbia respectively, where young people who rate their health higher tend to express higher social distance toward refugees.

All in all, our results show that the correlations between the observed variables are weak and in most cases statistically insignificant. The main conclusion of our study is that negative perceptions of immigrants and refugees are quite evenly spread across different segments of young people in terms of their financial situation, cultural background and health.

With this in mind, our second conclusion is that there is no universal pattern across countries or across different indicators; the observed correlations vary significantly between different societies and different measures. Within this volatility, Bulgaria comes out as the only country with a relatively stable pattern. This pattern, however, is the direct opposite to the one that we set out to find. In Bulgaria, betteroff young people tend to be more fearful of immigrants and refugees. It should be noted that Bulgaria also stands out as the country with the most pronounced fear of and social distance toward these groups of people. Further studies should therefore on the one hand focus on the macro-relationship between the frequency of negative attitudes toward immigrants and refugees, and correlations between these attitudes and different measures of the socio-economic status of individuals on the other.

\section{References}

Berggren, N. and Nilsson, T. (2013) “Does Economic Freedom Foster Tolerance?”. Kyklos, 66(2): p. 177-207.

Cavaille, C. and Marshall, J. (2017) "Education and anti-immigration attitudes: evidence from compulsory schooling reforms across Western Europe". American Political Science Review, 133 (1): p. 254-263.

Ceobanu, A. M. and Escandell, X. (2010) "Comparative Analysis of Public Attitudes Toward Immigrants and Immigration Using Multinational Survey Data. A Review of Theories and Research". Annual Review of Sociology 36, p. 309-328.

Chandler, C. R. and Tsai, Y. (2001) "Social Factors Influencing Immigration Attitudes: An Analysis of Data from the General Social Survey". The Social Science Journal 38, p. 177-188.

Coenders, M. and Scheepers, P. (2003) “The Effect of Education on Nationalism and Ethnic Exclusionism: An Internation Comparison”. Political Psychology 24, p. 313-343.

Espenshade, T. J. and Calhoun, C. A. (1993) "An Analysis of Public Opinion toward Undocumented Immigration”. Population Research and Policy Review 12(3), p. 189-224.

Davidov, E., Seddig, D., Gorodzeisky, A., Raijman, R., Schmidt, P., and Semyonov, M. (2019) "Direct and indirect predictors of opposition to immigration in Europe: individual values, cultural values, and symbolic threat". Journal of Ethnic and Migration Studies (0), p. 1-21. 
Das, J. DiRienzo, C. and Tiemann, T. (2008) “A global tolerance index”. Competitiveness Review, 18 (3): p. 192-205.

Diener, E. and Tov, W. (2007) "Subjective Well-Being and Peace". Journal of Social Issues, 63(2): p. 421-440.

Dimitrova, R., Buzea, C., Ljujic, L., Jordanov, V. (2015) "Nationalistic Attitudes and Perceived Threat Determine Romaphobia among Bulgarian and Romanian Youth". Revista de Asistent Social, 14(3): p. 33-47.

Florida, R., Mellander, C., Stolarick, K. (2009) "Talent, Technology and Tolerance in Canadian Regional Development”. Canadian Geographer, 10(1): p. 1-65.

Gang, I. N., Rivera-Batiz, F. and Yun, M. (2002) "Economic Strain, Ethnic Concentration and Attitudes toward Foreigners in the European Union". IZA Discussion Paper Series 578. Bonn: IZZA.

Goldschmidt, T. and Rydgren, J. (2017) "Social distance, immigrant integration, and welfare chauvinism in Sweden". Working paper. Available at: https://www. sociology.su.se/polopoly_fs/1.341801.1502441436!/menu/standard/file/wps22_2_ july2017complete.pdf (25.10.2019).

Gorodzeisky, A. (2011) "Who Are the Europeans That Europeans Prefer? Economic Conditions and Exclusionary Views toward European Immigrants". International Journal of Comparative Sociology 52(1-2), p. 100-113.

Hainmueller, J. and Hiscox, M. J. (2007) "Educated Preferences: Explaining Attitudes toward Immigration in Europe” International Organization 61(2), p. 399-442.

Heath, A., Davidov, E., Ford, R., Green, E. G. T., Ramos, A., and Schmidt, P. (2019) "Contested terrain: explaining divergent patterns of public opinion toward immigration within Europe". Journal of Ethnic and Migrants Studies, p. 1-14.

Herreros, F., and Criado, H. (2009) "Social Trust, Social Capital and Perceptions of Immigration”. Political Studies 57(2), p. 337-355.

Inglehart, R (2000) “Globalization and Postmodern Values”. Washington Quarterly, 23 (1): p. 215-228.

Inglehart, R. (2005) Modernization, Cultural Change, and Democracy: The Human Development Sequence. Cambridge University Press: Cambridge, New York, Melbourne, Madrid, Cape Town, Singapore, São Paulo.

Ivanova, V. (2018) "The wages of fear: attitudes towards refugees and migrants in Bulgaria”. Foundation Institute of Public Affairs, Warsaw. Available at: https://news. gallup.com/poll/240938/balkan-neighbors-hopefuls-worlds-apart-migrants.aspx

Kelley, J., Evans, M., D., R., Haller, M,. Jowell, R., Smith, T. (2009) "Economic development reduces tolerance for inequality. A comparative analysis of thirty Nations" in Charting the Globe: The International Social Survey Programme 19842009, London: Routledge.

Krange, O. (2001) "Anti-foreign sentiments among youth in Oslo: A matter of social stratification or invidiual identity formation”. Young 9(3), p. 43-64.

Kunovich, R. (2004) "Social Structural Position and Prejudice: An Exploration of CrossNational Differences in Regression Slopes”. Social Science Research 33, p. 20-44. 
Margaryan, S., Paul, A. and Siedler, T. (2018) "Does education affect attitudes towards immigration? Evidence from Germany". IZA Discussion paper series, no. 11980. Available at: https://www.econstor.eu/bitstream/10419/191628/1/1047094460.pdf (25.10.2019).

Markaki, Y. and Longhi, S. (2012) "What Determines Attitudes to Immigration in European Countries? An Analysis at the Regional Level". Norface Migration Discussion Paper 32. London: Norface.

Martínez Guillem, S. (2018). Race/ethnicity. In: Flowerdew, J., and Richardson, J. E. (eds.): The Routledge Handbook of Critical Discourse Studies. New York: Routledge, p. 359-360.

Mayda, A. M. (2005) "Who is Against Immigration? A Cross-Country Investigation of Individual Attitudes Towards Immigrants”. CEPR Discussion Paper 5055. Centre for Economic Policy Research, London.

Meuleman, B. Davidov, E. and Billiet, J. (2009) "Changing attitutes toward immigration in Europe, 2002-2007: A dynamic group conflict theory approach”. Social Science Research 38(2), p. 352-356.

Mierina, I. and Koroleva, I. (2015) "Support for far right ideology and anti-migrant attitudes among youth in Europe: A comparative analysis". The Sociological Review 63(2), p. 183-2015.

Miklikowska, M. (2017) "Development of anti-immigrant attitudes in adolescence: The role of parents, peers, intergroup friendships, and empathy”. British Journal of Psychology, 108(3): p. 626-648.

O’Rourke, K. H. and Sinnott, R. (2006) “The determinants of individual attitudes towards immigration”. European Journal of Political Economy 22, p. 838-861.

Paas, T. and Halapuu, V. (2012) "Attitutdes towards immigrants and the integration of ethnically diverse societies”. Norface Migration Discussion Paper, 2012-23.

Pamporov, A. (2009) "Social distances towards the new immigrants in Bulgaria". In: Migration from and to Southeastern Europe, ed. Anna Krasteva, Anelia Kasabova and Diana Karabinova. Centre for Migration, Refugees and Ethnic Studies: New Bulgarian University.

Paas, T. and Halapuu, V. (2012) "Attitutdes towards immigrants and the integration of ethnically diverse societies". Norface Migration Discussion Paper No. 2012-23.

Roots, A., Masso, A. and Ainsaar, M. (2016) "Measuring attitudes towards immigrants: validation of immigration attitude index across countries". First draft. European Social Survey Conference 'Understanding key challenges for European societies in the 21 st century'.

Rustenbach, E. (2010) "Sources of Negative Attitudes toward Immigrants in Europe: A Multi-Level Analysis”. The International Migration Review 44(1), p. 53-77.

Semyonov, M., Raijman, R. and Gorodzeisky, A. (2006) "The Rise of Anti-Foreigner Sentiment in European Societies, 1988-2000”. American Sociological Review 71, p. 426-449.

Vlase, I. and Preoteasa, A. M. (2017) "Romanians' current perception of threat from immigrants in a context of co-ethnic migration: assessing the role of intergroup conflict and active/passive contact". Southeast European and Black Sea Studies, 17 (3): p. 421-439. 


\title{
ДА ЛИ СЕ ДОБРОСТОЈЕЋИ МЛАДИ МАҢЕ ПЛАШЕ МИГРАНАТА И ИЗБЕГЛИЦА? СТУДИЈА СТАВОВА МЛАДИХ У ЈУГОИСТОЧНОЈ ЕВРОПИ
}

\begin{abstract}
Сажетак: Бројне студије повезују виши ниво образовања и опште благостање са нижим нивоима ксенофобије и социјалне дистанце у односу на странце. Ми смо тестирали ову општу претпоставку на узорку од више од 10000 младих у доби од 14 до 29 година из десет земаља југоисточне Европе. Тачније, фокус нашег истраживања био је процењивање утицаја финансијског статуса младих, нивоа образовања родитеља и самооцењеног здравственог стања на нивоу страха и социјалне дистанце у односу на мигранте и избеглице. Наша хипотеза била је да добростојећи млади у све три димензије (новац, образовање и здравље) показују мањи страх и већу отвореност према мигрантима и избеглицама у свакој од десет посматраних земаља. Анализе су показале да ниједна од шест тестираних хипотеза није могла да буде потврђена. Уз врло ретке изузетке, добростојећи млади немају позитивније перцепције миграната и избеглица. У суштини, наши резултати сугеришу да су негативне перцепције миграната и избеглица прилично равномерно распоређене у различитим сегментима популације младих, у погледу њихове финансијске ситуације, културног порекла и њиховог здравља. Једини делимични изузетак је Бугарска, где су корелације углавном супротне нашим очекивањима; боља финансијска ситуација и боље сомооцењено здравствено стање повезано је са негативнијим перцепцијама миграната и избеглица.
\end{abstract}

Кључне речи: мигранти, избеглице, млади, југоисточна Европа, страх, социјална дистанца 